\title{
ПІДГОТОВКА КВАЛІФІКОВАНИХ РОБІТНИКІВ В УМОВАХ ПТНЗ: ПРАКТИЧНИЙ АСПЕКТ
}

Стойчик Т. І. Підготовка кваліфікованих робітників в умовах ПТНЗ: практичний аспект.

У статті розглянуто актуальну проблему скорочення чисельності учнів професійнотехнічних навчальних закладів унаслідок демографічної кризи та обгрунтовано один із шляхів розв'язання проблеми дефіциту висококваліфікованої робочої сили методом паралельного навчання.

Ключові слова: професійно-технічний навчальний заклад, ВНЗ I-II рівня акредитації, робітнича кваліфікація, паралельне навчання.

Стойчик Т. И. Подготовка квалифицированных рабочих в условиях ПТУЗ: практический аспект.

В статье рассмотрена актуальная проблема сокращения численности учащихся профессионально-технических учебных заведений, вследствие демографического кризиса и обоснован один из путей решения проблемы дефицита высококвалифицированной рабочей силы методом параллельного обучения.

Ключевые слова: профессионально-техническое учебное заведение, вуз I-II уровня аккредитации, рабочая квалификация, параллельное обучение.

Stoychyk T. I. Training of skilled workers in vocational-technical schools: practical aspect.

The article deals with the current proplem of pupils number reduction in vocationaltechnical schools as a result of demographic crisis. One of the ways to solve the problem of well qualified labor shortage by using the method of parallel training is substantiated.

Key words: vocational-technical school, institution of hiqher I-II level of accreditation, working qualification, parallel training.

Після переходу України до ринкової моделі економіки виникає потреба змінювати застарілі підходи в галузі освіти, зокрема і професійно-технічної. Традиційна централізована система вже не може ефективно забезпечувати потреби сучасного ринку праці. Така ситуація створює для професійно-технічних навчальних закладів конкурентне середовище і спонукає змінювати підходи до підготовки, орієнтуючись передусім на вимоги ринку праці [2, с. 3].

Mema cmammi. На сучасному етапі багато уваги приділяється проблемам взаємодії між ринком праці та ринком освіти, розвитку системи професійно-технічної освіти в сучасних умовах, підвищенню іiі якості тощо, але мало звертається уваги на демографічний складник, який нині негативно впливає на розвиток системи професійно-технічної освіти.

Означена проблема спричинила необхідність пошуку шляхів переформатування підходів до підготовки кваліфікованих робітників в професійно-технічному навчальному закладі.

Низький рівень народжуваності у країні призводять до зменшення чисельності молоді, яка є джерелом поповнення навчальних закладів, у т. ч. і професійно-технічних. Так, за прогнозними даними Інституту демографії та соціальних досліджень ім. М. В. Птухи НАН України, кількість осіб у віці до 24 років зменшилась в 2009 році порівняно з 1990 роком на 
$25 \%$ [4].

Скорочення чисельності учнів призводить до неефективного функціонування професійно-технічних навчальних закладів, що в подальшому спричинить вивільнення приміщень, які разом із завеликою кількістю викладачів стануть додатковим тягарем для державного бюджету [1].

Одним із шляхів розв'язання проблеми є створення сучасних професійно-технічних навчальних закладів «відкритого» типу, де важливим залишається такий напрямок розвитку національної системи освіти України, як реалізація безперервної і якісної освіти.

Система безперервної професійної освіти реалізується в послідовному навчанні: школа - ПТНЗ - коледж - ВНЗ. В умовах вищеозначеної демографічної кризи, коли основна частина випускників шкіл формує контингент вищих навчальних закладів I-II рівнів акредитації, нівелюється освітньо-кваліфікаційний рівень - кваліфікований робітник. При цьому студент (навіть той, що успішно навчався у ВНЗ) не має навичок тривалої практичної діяльності і, як наслідок, реально не може ефективно керувати колективом, що складається в основному 3 кваліфікованих робітників [5, с. 44]. У такій ситуації деякі вищі технічні навчальні заклади зіткнулись із труднощами працевлаштування, коли кадровий потенціал не відповідає потребам підприємств [3, с. 4].

Провідні промислові підприємства Кривбасу засвідчують зацікавленість у першочерговому працевлаштуванні фахівців, які мають вищу освіту та робітничу кваліфікацію, або кваліфікованих робітників, які мають додаткову робітничу кваліфікацію поряд з основною, відповідно і практичні навички професійної діяльності.

Вищеозначене спонукало Криворізький професійний гірничо-технологічний ліцей до експериментування, зокрема надання можливості студентам ВНЗ одночасно 3 вищою освітою отримати робітничу кваліфікацію за суміжною професією, а учням ліцеюдодаткову робітничу кваліфікацію за суміжною професією.

Навчання в основному здійснювалось методом паралельного навчання за наскрізними навчальними планами, розробленими фахівцями навчального закладу разом зі спеціалістами Гірничого коледжу, Гірничо-електромеханічного коледжу, Криворізького автотранспортного коледжу ДВНЗ «Криворізький національний університет». Суть навчання полягала в тому, що:

- студент одночасно здобував первинну професійну підготовку на бюджеті у ВНЗ та в позаурочний час, за власні кошти здобував у ліцеї робітничу кваліфікацію за суміжною професією; або

- учень одночасно здобував первинну професійну підготовку в ліцеї на бюджеті та за власні кошти в цьому ж навчальному закладі здобував додаткову робітничу кваліфікацію за суміжною професією в позаурочний час.

Таблиия 1

\section{Інформація}

про студентів/учнів, які здобувають робітничу кваліфікацію за суміжною професією на базі Криворізького професійного гірничо-технологічного ліцею методом паралельного навчання

\begin{tabular}{|c|c|c|}
\hline $\begin{array}{c}\text { Назва навчального закладу, де } \\
\text { студенти/учні здобувають } \\
\text { первинну професійну } \\
\text { підготовку за бюджетні кошти }\end{array}$ & $\begin{array}{c}\text { Спеціальність за } \\
\text { основним місцем } \\
\text { навчання }\end{array}$ & $\begin{array}{c}\text { Робітнича кваліфікація, яку } \\
\text { студенти/ учні додатково } \\
\text { здобувають методом } \\
\text { паралельного навчання }\end{array}$ \\
\hline Гірничий коледж Державного & $5.05030102 \quad$ «Технологія & Машиніст бурової установки \\
\hline
\end{tabular}




\begin{tabular}{|c|c|c|}
\hline $\begin{array}{l}\text { Назва навчального закладу, де } \\
\text { студенти/учні здобувають } \\
\text { первинну професійну } \\
\text { підготовку за бюджетні кошти }\end{array}$ & $\begin{array}{c}\text { Спеціальність за } \\
\text { основним місцем } \\
\text { навчання }\end{array}$ & $\begin{array}{c}\text { Робітнича кваліфікація, яку } \\
\text { студенти/ учні додатково } \\
\text { здобувають методом } \\
\text { паралельного навчання }\end{array}$ \\
\hline \multirow{2}{*}{$\begin{array}{l}\text { вищого навчального закладу } \\
\text { «Криворізький національний } \\
\text { університет» }\end{array}$} & $\begin{array}{l}\text { підземної розробки } \\
\text { корисних копалин» }\end{array}$ & \\
\hline & $\begin{array}{l}5.05030104 \text { «Шахтне } \\
\text { підземне будівництво» }\end{array}$ & Гірник очисного забою \\
\hline \multirow[t]{3}{*}{$\begin{array}{l}\text { Гірничо-електромеханічний } \\
\text { коледж Державного } \\
\text { навчального } \\
\text { «Криворізький } \\
\text { університет» }\end{array}$} & $\begin{array}{l}5.05020103 \text { «Експлуатація } \\
\text { та ремонт гірничого } \\
\text { електромеханічного } \\
\text { обладнання та } \\
\text { автоматичних пристроїв» }\end{array}$ & $\begin{array}{llll}\text { Електрослюсар } & & \text { (слюсар) } \\
\text { черговий та } & 3 & \text { ремонту } \\
\text { устаткування } & & \end{array}$ \\
\hline & $\begin{array}{l}5.05070401 \text { «Зварювальне } \\
\text { виробництво» }\end{array}$ & Електрогазозварник \\
\hline & $\begin{array}{l}\text { 5.050701204 «Монтаж i } \\
\text { експлуатація } \\
\text { електроустаткування } \\
\begin{array}{l}\text { підприємств і цивільних } \\
\text { споруд» }\end{array} \\
\end{array}$ & $\begin{array}{l}\text { Електромонтер } 3 \text { ремонту та } \\
\text { обслуговування } \\
\text { електроустаткування }\end{array}$ \\
\hline \multirow{2}{*}{$\begin{array}{lr}\text { Автотранспортний } & \text { коледж } \\
\text { Державного } & \text { вищого } \\
\text { навчального } & \text { «акладу } \\
\text { «Криворізький } & \text { національний } \\
\text { університет» } & \end{array}$} & $\begin{array}{l}5.05070205 \\
\text { «Обслуговування і ремонт } \\
\text { автомобілів та тракторів» }\end{array}$ & Слюсар з ремонту автомобілів \\
\hline & $\begin{array}{l}\text { 5.05050213 «Експлуатація } \\
\text { засобів механізації та } \\
\text { автоматизації } \\
\text { перевантажувальних } \\
\text { робіт» }\end{array}$ & Слюсар з ремонту автомобілів \\
\hline
\end{tabular}

Дисципліни, що вивчались під час первинної професійної підготовки за умови атестації учня, зараховувались як академічна різниця при паралельному навчанні. Як правило, таке навчання здійснювалось на третьому курсі первинної професійної підготовки (рис.1).

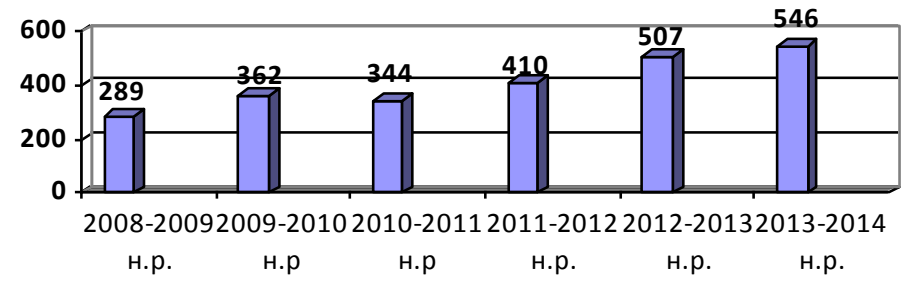

Рис. 1. Кількість учнів, які пройшли паралельне навчання за суміжними професіями у BHЗ I-II рівня акредитації та в Криворізькому професійному гірничо-технологічному ліцеї.

Переваги означеної системи навчання полягають у тому, що:

- упровадження не потребує додаткових бюджетних коштів;

- студенти вищих навчальних закладів мають можливість здобути робітничий розряд за суміжною професією зі скороченим терміном;

- студенту вдається здобути суміжну робітничу кваліфікацію та найбільш раціонально використовувати відведений для навчання період часу;

- розширюються можливості професійно-технічних навчальних закладів щодо 
надання освітніх послуг;

- збільшуються перспективи працевлаштування випускників вищих навчальних закладів;

- розв'язується проблема дефіциту робітничих кадрів в умовах сучасного ринку праці;

- оволодіння кількома суміжними робітничими кваліфікаціями значною мірою допоможе випускнику адаптуватися в соціально-економічних i технологічних умовах виробництва, що постійно змінюються.

Разом $з$ тим, організація такої системи підготовки передбачає дотримання положення, пов'язаного з тим, що людина має право займати бюджетне місце тільки один раз за весь час свого навчання. Якщо студент/учень навчається у ВНЗ/ПТНЗ на бюджеті, то він уже не має права займати бюджетне місце про одержанні робітничої кваліфікації/додаткової робітничої кваліфікації. Утім бюджетник може сплачувати за своє навчання робітничої професії зі стипендії.

Використання паралельного навчання дозволить послабити проблему дефіциту висококваліфікованої робочої сили внаслідок старіння населення і недостатньої кількості молоді, сприятиме підвищенню престижності професійно-технічної освіти, надасть змогу розширити можливості професійно-технічних навчальних закладів щодо надання освітніх послуг, при цьому значно скоротити витрати на підготовку.

\section{Література}

1. Заюков І. В. Перспективи розвитку професійно-технічної освіти в умовах демографічної кризи України [Електронний ресурс] / I. В. Заюков. - Режим доступу до документа: http://nauka.kushnir.mk.ua/ - Заголовок 3 екрану. 2. Інститутуційний розвиток ПТНЗ: основні підходи до бізнес-планування та маркетингу: [навч.-метод. посібн.]/ Даниленко Л. І., Сергеєва Л. М., Кашевський В. В. та ін.; / за ред. Л. І. Даниленко. - Київ: ТОВ «Етіс Плюс», 2008. - 148 с. З. Лузан П. Г. Формування змісту професійного навчання кваліфікованих робітників 3 інтегрованих професій: [метод. посібн.] / П. Г. Лузан, Ю. І. Кравець, Т. В. Пятничук. - Київ : Інститут ПТО НАН України, 2012. - 136 с. 4. Офіційний сайт Інституту демографії та соціальних досліджень ім. М. В. Птухи НАН України [Електронний pecypc].- Режим доступу до документа: http/l http://www.idss.org.ua/http://nauka.kushnir.mk.ua/. - Заголовок 3 екрану. 5. Сушенцева Л. Л. Оволодіння студентами робітничими професіями у ПТНЗ: аналіз досвіду / Л. Л. Сушенцева, О. Д. Учитель. // Професійно-технічна освіта. -2013. - № 3. - С. 45.

УДК 378.147-057

Ростислав Тарасенко

\section{ДІЯЛЬНІСНИЙ КОМПОНЕНТ ІНФОРМАЦЙНОЇ КОМПЕТЕНТНОСТІ МАЙБУТНІХ ПЕРЕКЛАДАЧІВ: ЗМІСТ, ФОРМУВАННЯ, ДІАГНОСТИКА}

Тарасенко Р. О.Діяльнісний компонент інформаційної компетентності майбутніх перекладачів: зміст, формування, діагностика.

Розглянуто питання формування діяльнісного компонента інформаційної компетентності майбутніх перекладачів. Визначено групи умінь як складників діяльнісного компоненту. Окреслено шляхи їх формування. Розроблено зміст виробничої практики, спрямованої на закріплення визначених умінь. Обгрунтована доцільність діагностики рівнів 